$\begin{array}{r}\text { Phinisi Integration Review } \\ \text { Vol. 2, No.1, Februari 2019 Hal 047-054 } \\ \text { Website: http://ojs.unm.ac.id/pir } \\ \text { p-ISSN: 2614-2325 dan e-ISSN: 2614-2317 } \\ \hline\end{array}$

\title{
Perilaku Menyimpang
}

\section{Studi Kasus Perilaku Seks diluar Nikah Mahasiswa Kos-Kosan Alauddin Kelurahan Mangasa Kecamatan Tamalate Kota Makassar}

\author{
Syahban Nur ${ }^{(1)}$ \\ Dosen Sosiologi FKIP \\ Universitas Muhammadiyah Makassar \\ e-mail : syahban@unismuh.ac.id
}

\begin{abstract}
Abstrak. Penelitian ini adalah penelitian kualitatif melalui pendekatan studi kasus yang bertujuan (i) untuk menganalisis terjadinya perilaku seks diluar nikah pada mahasiswa kos-kosan di daerah Alauddin, (ii) untuk mengetahui faktor-faktor penyebab terjadinya perilaku seks diluar nikah pada mahasiswa kos-kosan di daerah Alauddin, (iii) untuk mengetahui tanggapan tokoh masyarakat terhadap perilaku seks diluar nikah pada mahasiswa di daerah Alauddin. Adapun populasi penelitian adalah mahasiswa kos-kosan di daerah alaudin dan pengambilan sampel mengunakan teknik penentuan informan linear snowball sampling Metode pengumpulan data adalah observasi, wawancara, dan dokumentasi. Hasil penelitian menunjukkan bahwa terjadinya perilaku seks diluar nikah pada mahasiswa kos-kosan daerah Alaudin karena disebabkan oleh kurangnya kontrol dari pemilik kos, orang tua dan kekuatan cinta sehingga perilaku seks tersebut marak terjadi dikalangan mahasiswa khususnya mahasiswa kos-kosan daerah Alauddin, Faktor determinan yang menjadi penyebab munculnya perilaku seks diluar nikah adalah faktor internal karena benturan ekonomi dari mahasiswa itu sendiri, perasan cinta, kontrol pemilik kos, tanggapan tokoh masyarakat terkait perilaku seks diluar nikah pada mahasiswa kos-kosan daerah Alauddin adalah kurangnya respon masyarakat terhadap perilaku seks yang dilakukan oleh mahasiswa.
\end{abstract}

Kata Kunci: perilaku seks; kualitatif; mahasiswa kos-kosan

Abstract. This research is qualitative take casus study which is aimed (i) to analyze the
occurrence of premarital sex behavior of the students who lived in boarding houses in
Alauddin area, (ii) to discover the factors which caused premarital sex behavior of the
students who lived in boarding houses in Alauddin area, (iii) to discover the responses of
community figure toward premaritas sex behavior of the students who lived in boarding
houses in Alauddin area. research population is the students who lived in boarding houses
in Alauddin area.the informants were determined by using linear snowball sampling
technique. The data of the research were collected by using observation, interview, and
documentation methods. The results of the research revealed that (i) the occurrence of
premarital sex behavior of the students who lived boarding houses in Alauddin area was
caused by lack of control of boarding house owners, parents and the power of love, so sex
behavior always happening to students, particulary studentds who lived in boarding
houses in Alauddin area, (ii)the determinant factors which caused premarital sex behavior
werw economic clash pf students themselves, feeling in love, and boarding houses
owners control,(iii) the responses of community figures related to premarital sex behavior 
of students who live in boarding house in Alauddin area werw lack of community responses towards sex behavior performed by the students.

Keywords: sex behavior; qualitative; students

(c) (7) (8) Ini adalah artikel dengan akses terbuka dibawah licenci CC BY-NC-4.0 (https://creativecommons.org/licenses/by-nc/4.0/ ).

\section{PENDAHULUAN}

Manusia merupakan makhluk Tuhan yang selalu membutuhkan pasangan dalam menjalankan kehidupan di dunia, karena manusia merupakan mahluk sosial yang tidak dapat hidup tanpa bantuan manusia lainnya. Apalagi dikaitkan dengan apa yang menjadi anugrah dari Tuhan yaitu hawa nafsu. Oleh karen itu, dalam pemenuhan akan kebutuhan nafsu yang dimiliki manusia tentu akan membutuhkan akan pasangan hidup. Hal tersebut terbukti dari sejarah awal lahirnya manusia yaitu Nabi Adam AS sebagai manusia pertama diciptakan Tuhan yang tidak bisa hidup tenang tanpa hadirnya Siti Hawa sebagai teman hidupnya.

Berangakat dari hal tersebut, maka manusia memang merupakan mahluk yang sangat membutuhkan pasangan guna untuk memenuhi kebutuhan hidupnya terlebih lagi dalam memenuhi kebutuhan akan biologisnya. Olehnya itu, manusia sangat membutuhkan pasangan untuk memenuhi kebutuhan akan seksual. Seks merupakan salah satu kebutuhan bagi manusia, sehingga dalam memenuhi kebutuhan seks tersebut seringkali manusia melakukan segala hal, seperti melakukan hubungan perkawinan bahkan hubungan diluar pernikahan atau yang sering disebut seks bebas.

Meskipun seks merupakan salah satu kebutuhan manusia, namun dalam pemenuhannya tidak terlepas dari norma-norma yang ada di masyarakat. Karena manusia adalah mahluk sosial yang memiliki aturan yang membatasi mereka dalam menjalankan kehidupan. Oleh karena itu, manusia tidak terlepas dari aturan-aturan yang ada dalam masyarakat dalam memenuhi kebutuhan akan seks, sehingga jika hubungan tersebut terjadi di luar batas norma yang ada maka tergolong dalam perilaku menyimpang karena melanggar norma yang ada dalam masyarakat sehingga dinamakan seks bebas.

Adapun seks bebas yang merupakan hubungan intim seseorang diluar nikah dan merupakan sebuah perilaku menyimpang yang seringkali dikerjakan oleh manusia terutama dikalangan mahasiswa saat ini. Pada kalangan anak kos-kosan perilaku seks bebas juga sering terjadi apa lagi pada kos-kosan yang diberi kebebasan oleh pemilik kos. Dalam hal ini, dapat dilihat pada kos-kosan di Daerah Alauddin.

Adapun Daerah Alauddin merupakan salah satu daerah yang didominasi oleh masyarakat muslim, yang memegang teguh keluhuran dan adat istiadat, terlebih lagi dengan adanya budaya "Siri" (dalam istilah Bugis Makassar). Budaya "siri" merupakan budaya yang sangat dipegang teguh oleh masyarakat Bugis Makassar pada umumnya. Namun kenyataannya dibalik adanya budaya tersebut sering terdapat perilakuperilaku yang tidak sesuai dengan apa yang tidak diinginkan oleh masyarakat Bugis Makassar, seperti halnya dengan maraknya perilaku seks bebas Mahasiswa Kos-Kosan di Daerah Alauddin. Hal tersebut terbukti dengan seringnya terjadi kasus penggerebekan seperti yang terjadi tahun lalu, bahwa polisi gerebek pasangan mahasiswa di kamar kos.

(Makassar.tribunnews.com/2015/02/03)

Kasus diatas merupakan salah satu gambaran bahwa para mahasiswa saat ini sudah tercemar dengan prilaku yang tidak sewajarnya akan dilakukan oleh mahasiswa karena sesungguhnya mahasiswa merupakan cikal bakal harapan bangsa. Namun bisa dikatakan memiliki kualitas moral yang rendah dengan terjadinya kasus-kasus seks bebas tersebut. Sebagaimana yang telah diketahui bahwa, mahasiswa merupakan gambaran masa depan bangsa, sehingga hancur dan berjayanya suatu bangsa dimasa depan banyak bergantung dari kondisi mahasiswanya saat ini. 


\section{Syahban Nur. Perilaku Menyimpang Studi Kasus Perilaku Seks diluar Nikah Mahasiswa Kos-Kosan Alauddin Kelurahan Mangasa Kecamatan Tamalate Kota Makassar}

Namun kenyataannya berbanding terbalik dengan nuansa yang tergambar dari Bugis Makassar yang terkenal dengan kesan agamais, beradat dan bermoral. Hal ini tercermin dari banyak terdapat Universitas yang bergerak dibidang keislaman seperti Unismuh Makassar, UIN Makassar, UMI di Kota Makassar sebagai tempat menimba ilmu yang out put-nya kelak ialah melahirkan generasi yang beradab sesuai dengan nilai dan ajaran agama dan harapan masyarakat, dimana masyarakat Bugis Makassar yang terkenal dengan masyarakat yang memegang teguh akan norma dan adat istiadat, namun seringkali terjadi perilaku mahasiswa yang melakukan seks bebas, maka peneliti merasa tergetar untuk mengkaji lebih dalam tentang perilaku seks bebas Mahasiswa di Daerah Alauddin.

Selanjutnya, jika di kaitkan dengan karakter masyarakat Daerah Alauddin, maka sangatlah tidak wajar jika terjadi perilaku seks bebas tersebut, apa lagi jika dilihat pula dengan adanya pusat-pusat pendidikan yang terdapat di Kota Makassar. Namun kebanyakan perilaku seks bebas yang dilakukan oleh para mahasiswa cendrung terjadi di lingkungan pendidikan. Oleh karena itu, banyak sekali para akademisi yang mengkaji mengenai prilaku seks dikalangan remaja seperti yang dilakukan oleh Anna Salisa pada tahun 2010, yang mengkaji tentang perilaku seks bebas dikalangan mahasiswa.

Adapun hasil dari penelitian yang dilakukan oleh Anna Salisa (2010) menyatakan bahwa faktor-faktor penyebab munculnya perilaku seks pranikah beradasarkan hasil penelitian diantaranya karena kegagalan fungsi keluarga, hal ini memicu mereka untuk berperilaku bebas bahkan melanggar norma sekalipun, karena merasa tidak ada yang peduli atau mencegah hal tersebut. Selanjutnya, pengaruh media, hal tersebut menunjukkan bahwa media sangat berpengaruh terhadap perilaku seks pranikah. Kemudian rendahnya pendidikan nilai-nilai agama, hal tersebut nampak dari pendapat para responden yang mengakui bahwa mereka masih belum memahami pendidikan agama yang mereka peroleh selama ini. Menunjukkan bahwa pendidikan agama yang mereka peroleh selama duduk dibangku sekolah sangat minim.

Berdasarkan hasil penelitian yang di ungkapkan oleh penelitian terdahulu sebagaimana yang saya baca, maka bisa disimpulkan bahwa prilaku seks bebas yang dilakukan oleh para mahasiswa saat ini didasarkan atas kurangnya pendidikan agama dan pendidikan moral dikalangan mahasiswa saat ini. Olehnya itu, berangkat dari hasil penelitian tersebut maka dalam kajian ini akan menelusuri atau mengkaji mengenai perilaku seks bebas pada mahasiswa kos-kosan yang terjadi di tengah-tengah masyarakat yang memegang teguh kebudayaan yang dimiliki masyarakat Bugis Makassar, sehingga dalam penelitian ini akan mengkaji penyebab dari terjadinya prilaku menyimpang tersebut.

Adapun yang melatar belakangi peneliti mengangkat judul Perilaku Menyimpang (Studi Kasus Perilaku Seks Diluar Nikah Mahasiswa Kos-kosan Alauddin kelurahan Mangasa kecamatan Tamalate) adalah karena didasarkan atas kegalauan peneliti terhadap fenomena yang terjadi pada Mahasiswa yang berdomisili di daerah Alauddin tentang perilaku seks bebas yang marak terjadi di tengah-tengah masyarakat yang memegang teguh budaya "Siri". Selain itu juga, Saya merasa perilaku seks bebas ini seperti warisan yang turun temurun diwariskan dari gaya hidup senior ke junior, dan Saya merasa khawatir terhadap prilaku mahasiswa yang terjadi di daerah Alauddin, sehingga peneliti akan mengkaji dan menganalisis setiap permasalahan yang menyebabkan prilaku menyimpang tersebut terjadi dikalangan mahasiswa kos-kosan saat ini di daerah Alauddin.

\section{METODE PENELITIAN}

Jenis penelitian ini adalah kualitatif melalui pendekatan studi kasus di kota Makassar. Instrument penelitian ini adalah peneliti sendiri (human instrument) dengan menggunakan alat bantu berupa pedoman wawancara, instrument dokumentasi dan catatn observasi, alat perekam dan kamera. Pemilihan informan dilakukan secara linear snowball sampling. Focus penelitian perilaku seks diluar niikah pada mahasiswa kos-kosan. Jenis data terdiri dari data primer dan sekunder. Teknik pengumpulan data menggunakan metode observasi, wawancara mendalam, dokumentasi. Analisis data dilakukan melalui tahapan reduksi data (data reduction), penyajian data (display data) verivication dan penarikan kesimpulan. Sedangkan teknik keabsahan data meliputi uji 


\section{Syahban Nur. Perilaku Menyimpang Studi Kasus Perilaku Seks diluar Nikah Mahasiswa Kos-Kosan Alauddin Kelurahan Mangasa Kecamatan Tamalate Kota Makassar}

credibility (validitas internal), transferability (validitas eksternal), dependability (reliabilitas) dan confirmability (objektivitas).

\section{HASIL DAN PEMBAHASAN}

\section{Terjadi Perilaku Seks Bebas diluar Nikah pada Mahasiswa Kos-Kosan Alauddin}

Perkembangan fisik termasuk organ seksual yaitu terjadinya kematangan serta peningkatan kadar hormon reproduksi atau hormon seks baik pada laki-laki maupun pada perempuan yang akan menyebabkan perubahan perilaku seksual Mahasiswa secara keseluruhan. Pada kehidupan psikologis Mahasiswa, perkembangan organ seksual mempunyai pengaruh kuat dalam minat Mahasiswa terhadap lawan jenis.

Terjadinya peningkatan perhatian Mahasiswa terhadap lawan jenis sangat dipengaruhi oleh faktor perubahan-perubahan fisik selama periode pubertas. Mahasiswa perempuan lebih memperlihatkan bentuk tubuh yang menarik bagi Mahasiswa laki-laki, demikian pula Mahasiswa pria tubuhnya menjadi lebih kekar yang menarik bagi Mahasiswa perempuan.

Pada masa Mahasiswa rasa ingin tahu terhadap masalah seksual sangat penting dalam pembentukan hubungan yang lebih matang dengan lawan jenis. Matangnya fungsi-fungsi seksual maka timbul pula dorongan-dorongan dan keinginan-keinginan untuk pemuasan seksual. Sebagian besar dari Mahasiswa biasanya sudah mengembangkan perilaku seksualnya dengan lawan jenis dalam bentuk pacaran atau percintaan. Bila ada kesempatan para Mahasiswa melakukan sentuhan fisik, mengadakan pertemuan untuk bercumbu bahkan kadang-kadang Mahasiswa tersebut mencari kesempatan untuk melakukan hubungan seksual. Selain itu, berdasarkan dari hasil penelitian dilapangan bahwa salah satu yang menyebabkan perilaku seks tersebut terjadi pada kalangan Mahasiswa khususnya di Kelurahan Mangasa adalah sebagai berikut:

a. Kurangnya kontrol pemilik kos

Berbicara kontrol dari pemilik kos memang sangat penting apalagi menyangkut dengan sebuah perilaku Mahasiswa. Dalam hal ini, seorang Mahasiswa harus mendapat kontrol dari pemilik kos karena jika di berikan sebuah kebebasan maka akan menimbulkan perilaku yang tidak sesuai dengan norma yang berlaku. Namun kenyataannya sekarang ini, seringkali para pemilik kos memberikan kebebasan terhadap para penyewa kos sehingga dapat mengakibatkan perilaku seks bebas terjadi pada kalangan Mahasiswa di kos-kosan.

Berdasarkan hasil penelitian bahwa di beberapa tempat kos yang ada di Kelurahan Mangasa yang pemiliknya memberikan kebebasan terhadap para penyewa kos atau Mahasiswa karena alasannya bahwa jika kos tersebut diberikan kebebasan maka sangat disenangi oleh para penyewa kos terutama para Mahasiswa. Oleh karena itu, pada perilaku seks bebas dikalangan Mahasiswa berdasarkan hasil penelitian bahwa terjadinya perilaku tersebut karena disebabkan kurangnya kontrol dari sang pemilik kos-kosan.

b. Perhatian orang tua

Orang tua merupaka pengontrol dari perilaku Mahasiswa, pada masa Mahasiswa orang tua harus berperan aktif dalam menjaga dan mengontrol perilaku sang Mahasiswa sehingga tidak melakukan hal yang dilarang oleh agama dan tidak sesuai dengan norma yang berlaku. Berdasarkan hasil penelitian bahwa kontrol orang tua sangat tidak afektiv dalam menjaga tingkah laku Mahasiswanya sehingga terjadi hal hal yang tidak diinginkan seperti perilaku seks bebas pada kalangan Mahasiswa.

c. Kekuatan rasa cinta

Seringkali kekuatan cinta terkadang menjerumuskan kearah yang negatif, oleh karena itu dari hasil penelitian bahwa kekuatan cinta dapat menjadikan para Mahasiswa melakukan seks bebas khususnya para Mahasiswa kos-kosan. Para informan beralasna bahwa mereka melakukan hal tersebut karena didasarkan atas cinta.

Namun sebenarnya dari tiga hal yang menjadi penyebab terjadinya perilaku seks bebas dikalangan Mahasiswa kos-kosan tersebut perlu juga dilihat pelaku atau Mahasiswanya itu sendiri. Mahasiswa merupakan orang yang sudah memiliki pemikiran yang tinggi apalagi para Mahasiswa tersebut sudah berada pada tinggkat pendidikan tingga. Oleh karena itu, Mahasiswa melakukan hal tersebut merupakan pilihan mereka, sehingga perilaku Mahasiswa itu jika di analisis menggunakan teori tindakn Weber maka perilaku para Mahasiswa tersebut termasuk dalam tipe tindakan apektif yaitu tindakan yang biasanya dikuasai oleh perasaan atau emosi tanpa memperhitungkan akal budi. Seringkali tindakan ini dilakukan tanpa 


\section{Syahban Nur. Perilaku Menyimpang Studi Kasus Perilaku Seks diluar Nikah Mahasiswa Kos-Kosan Alauddin Kelurahan Mangasa Kecamatan Tamalate Kota Makassar}

perencanaan matang dan tanpa kesadaran penuh dan dapat dikatakan tindakan yang dilakukan merupakan reaksi spontan atas suatu peristiwa.

Weber dalam teorinya membedakan tindakan dengan prilaku yang murni reaktif. Adapaun perilaku yang dimaksudkan Weber dalam hal ini adalah perilaku otomatis yang tidak melibatkan proses pemikiran. Weber memusatkan perhatian pada tindakan yang jelas-jelas melibatkan campur tangan proses pemikiran (tindakan bermakna yang ditimbulkan olehnya) antara terjadinya stimulus dengan respon. Sehingga tindakan dikatakan terjadi ketika individu meletakkan makna subjektif pada tindakan mereka. Sehingga, jika dikaitkan dengan prilaku seks bebas dikalangan Mahasiswa, dalam hal ini, para Mahasiswa yang melakukan prilaku seks bebas dilingkungan kos-kosan karena ada stimulus yang menimbukan pasangan atau lawan jenis terespon untuk melakukan prilaku seks tersebut.

\section{Faktor-faktor yang menjadi penyebab determinan terjadinya perilaku seks bebas diluar nikah pada Mahasiswa Kos-Kosan Alauddin}

Beberapa faktor yang menyebabkan terjadinya perilaku seks bebas diluar nikah pada Mahasiswa di Kelurahan Mangasa khususnya pada Mahasiswa kos-kosan adalah:

a. Faktor internal

1) Peran Keluarga

Kegagalan fungsi keluarga dalam memainkan perannya sebagai tempat awal kehidupan Mahasiswa merupakan faktor marak terjadinya perilaku seks bebas di kalangan Mahasiswa. Berdasarkan data hasil penelitian, menunjukkan bahwa informan (yang melakukan perilaku seks bebas) kurang mendapat perhatian dari orang tua perilaku yang dilakukan sehubungan dengan perilaku seks bebas, apakah pantas atau tidak, bahkan tidak peduli jika anaknya melakukan perilaku seks bebas yang sebenarnya menyimpang dari norma yang berlaku.

Para orang tua telah gagal dalam menanamkan pendidikan agama pada anak-anak mereka. Pada zaman sekarang ini, banyak orang tua yan lebih mengutamakan mengejar ilmu umum atau hal-hal yang bersifat materi dibandingkan dengan keagamaan. Berdasarkan observasi, telah menunjukkan bahwa orang tua kurang memperhatikan perilaku anak-anak mereka, sehingga anak mereka bebas dan seolah-olah tidak ada aturan tentang bagaimana seharusnya mereka berperilaku.

Keluarga, khususnya orang tua seharusnya menjadi pengontrol gerak langkah anakanaknya, melalui pendidikan agama yang mendalam serta menerapkannya dalam kehidupan sehari-hari. Namun jika fungsi tak dilaksanakan sebagaimana mestinya, sebagai anak yang merasa kurang diperhatikan dalam keluarganya sendiri, maka hal itu dapat memicu terjadinya berbagai penyimpangan.

Sesuai dengan penjelasan diatas, maka dalam teori Weber yaitu tidakan sosial. Dimana dalam hal ini, tindakan tersebut masuk dalam tindakan sosial dengan tipe tindakan afektif yaitu merupakan tindakan yang ditentukan oleh kondisi kejiwaan dan perasaan aktor yang melakukan untuk mencapai keinginan aktor tersebut seperti yang dilakukan pada Mahasiswa sekarng ini khususnya yang ada di Kelurahan Mangasa . Oleh karena itu, perilaku tersebut dapat menimbulkan kontroversi dalam berbagai lapisan masyarakat.

2) Kebutuhan Ekonomi

Berdasarkan dari hasil penelitian bahwa ekonomi merupakan faktor penyebab dari munculnya perilaku seks di kalangan Mahasiswa saat ini, terutama pada Mahasiswa perempuan. Dengan begitu banyak kebutuhan yang mereka inginkan untuk tercapai, maka olehnya itu, berbagai cara yang mereka lakukan demi tercapainya keinginannya.

Dari hasil wawancara dengan beberapa informan yang menjadi aktor dalam permasalahan ini maka dapat di simpulkan para Mahasiswa melakukan perilaku seks bebas tersebut karena di dasarkan atas benturan ekonomi. Namun dalam hal ini, bila dikaitkan dengan teori tindakannya Weber yang merupakan landasan pemikiran (teori) dalam mengkaji permasalahan seks bebas di kalangan Mahasiswa khususnya di Kelurahan Mangasa tersebut maka hal ini sangatlah terbukti karena mereka melakukan tersebut atas dasar tujuan yang ingin di capai.

\section{b. Faktor eksternal}

1) Lingkungan pergaulan

Pengaruh lingkungan memegang peran yang tidak kecil terhadap perubahan atau terjadinya suatu pola perilaku. Dalam suatu lingkungan terjadi tindakan sosial yang merupakan suatu proses dimana aktor terlibat dalam mengambil keputusan-keputusan subyektif tentang saranasarana dan cara untuk mencapai tujuan tertentu 


\section{Syahban Nur. Perilaku Menyimpang Studi Kasus Perilaku Seks diluar Nikah Mahasiswa Kos-Kosan Alauddin Kelurahan Mangasa Kecamatan Tamalate Kota Makassar}

yang telah dipilihnya dan kesemuanya itu dibatasi kemungkinan-kemungkinannya oleh sistem kebudayaan dalam bentuk norma, ide-ide, kepribadian serta norma sosial.

Manusia pada dasarnya tidak dapat hidup seorang diri karena pada hakekatnya manusia memiliki naluri untuk hidup bersama (berkelompok). Dalam kelompok-kelompok itulah individu memiliki kepentingan yang tentunya berbeda dengan individu satu dengan yang lainnya. Demi menjaga kepentingan diantara mereka maka dibentuklah peraturan, norma, nilai, etika yang diharapkan nantinya dapat menjaga keseimbangan didalamnya hidup bersama (bermasyarakat). Dan ketika interaksi dan segala aktivitas masyarakat berlangsung maka muncullah konstruksi kenyataan sosial (social contruction of reality).

Kenyataan sosial sebagai suatu proses dimana melalui tindakan-tindakan dan interaksinya manusia menciptakan terus-menerus suatu kenyataan yang dimiliki bersama. Pengetahuan akan berbagai faktor obyektif dalam dunia kenyataan ditentukan (conditioned) atau di warnai oleh lingkungan sosial dimana pengetahuan itu di peroleh, di transmisikan, atau di pelajari. Dengan kata lain kita tidak pernah menangkap kenyataan kecuali dalam kerangka proses sosial dimana kita terlibat.

Dari hasil penelitian diperoleh data bahwa dengan keberadaan Mahasiswa di lingkungan yang kurang memadai, misalnya dekat dengan tempat pelacuran, maka kemungkinan akan terjadinya perilaku seks bebas semakin besar. Juga adanya lingkungan teman-teman bergaulnya, dimana kebanyakan dari mereka melakukan seks pranikah, hal itu juga akan mendorong si Mahasiswa untuk mengikuti pola perilaku seks tersebut.

\section{2) Pengaruh media}

Dengan berkembangnya berbagai media, baik elektronik maupun cetak, manusia menyebarkan budaya apapun yang kadang-kadang merefleksikan nilai-nilai yang berbeda dengan pemakainya. Misalnya, ide tentang kebebasan sesual ditayangkan secara explisit dan sangat jelas tanpa ada sensor apapun yang adekuat untuk anak-anak. Sebagian besar Mahasiswa menyatakan butuh nasihat mengenai seks dan kesehatan reproduksi.

Tetapi sebagian besar Mahasiswa justru tidak dapat mengakses sumber informasi yang tepat. Jika mereka kesulitan untuk mendapatkan informasi melalui jalur formal, terutama dari lingkungan sekolah dan petugas kesehatan, maka kecenderungan yang muncul adalah cobacoba sendiri mencari sumber informal. Maraknya informasi yang negatif tersebut oleh Mahasiswa dipenuhi dengan cara membahas bersama teman-teman, buku-buku tentang seks, atau mengadakan percobaan dengan jalan masturbasi, bercumbu atau berhubungan seksual.

Kebanyakan masih ada anggapan, seksualitas dan kesehatan reproduksi dinilai masih tabu untuk dibicarakan Mahasiswa. Karena banyaknya informasi seksualitas yang tidak benar dan tidak sesuai dengan nilai-nilai agama bagi anak-anak dan Mahasiswa, maka perlu dirumuskan pendidikan seksualitas mereka sehingga bisa membedakan dengan jelas antara pendidikan seksualitas yang mencakup nilainilai agama dengan pendidikan seksualitas yang sekuler atau yang tidak berdasarkan nilai-nilai agama.

Kalau tidak, akan ada kemungkinan bahwa para generasi akan mendapatkan efek negatif dari informasi seksualitas yang tidak agamis dan tidak sehat berupa terkena atau tertular penyakit sexual dan juga mungkin akan kehilangan nilainilai Islam dalam bersikap dan perilakunya yang terkait dengan seksualitas.

Dari hasil penelitian dengan responden mengatakan bahwa media sangat berpengaruh terhadap perilaku mahasiswa, responden mengakui hal itu cukup berpengaruh. Hal ini bisa diartikan bahwa media dengan bebas menyiarkan acara-acara dan tayangan-tayangan yang berkiblat perilaku seks pra nikah. Beberapa tahun terakhir, menjamurnya stasiun TV swasta yang saling bersaing satu sama lain seolah-olah membuka lebar kebebasan pers yang dengan tanpa malu menyiarkan tayangantayangan yang berkiblat ke budaya barat, yang mengakibatkan munculnya peniruan oleh kalangan generasi muda. Pada Mahasiswa selalu ingin tampil modis, menarik dan mengikuti perkembangan zaman, sehingga mengabaikan norma-norma yang berlaku di masyarakat Adapun dari kedua faktor yang menyebabkan perilaku seks bebas di kalangan Mahasiswa tersebut namun yang menjadi faktor determiannya adalah faktor internal. Hal ini dikarenakan bahwa perilaku seks bebas yang sering terjadi pada kalangan Mahasiswa tersebut adalah didasarkan atas rasa cinta yang sangat 


\section{Syahban Nur. Perilaku Menyimpang Studi Kasus Perilaku Seks diluar Nikah Mahasiswa Kos-Kosan Alauddin Kelurahan Mangasa Kecamatan Tamalate Kota Makassar}

berlebihan dan kurangnya perhatian dari pemilik kos dan orang tuanya. Oleh karena itu, dengan benturan ekonomi, kesempatan yang ada di maka aitulah yang menjadi stimulus dari para Mahasiswa untuk melakukan perilaku seks bebas tersebut, apalagi dalam hal ini di tambah dengan rasa cinta yang sangat berlebihan dari Mahasiswa tersebut. Oleh karena itu dalam hal ini, terjadinya perilaku seks bebas di kalangan Mahasiswa karena faktor internal.

Upaya yang dilakukan oleh pihak berwenang dalam mengatasi Perilaku seks bebas diluar nikah pada Mahasiswa Kos-Kosan di Daerah Alauddin.

Berdasarkan dari beberapa pandangan masyarakat terkait dengan perilaku seks bebas diluar nikah pada Mahasiswa khususnya Mahasiswa yang kos-kosan di Kelurahan Mangasa, bahwa perilaku tersbut memang benar terjadi. Numun dengan lepas kontrolnya masyarakat terhadap apa yang menjadi perilaku Mahasiswa tersebut sehingga menyebabkan maraknya seks bebas diluar nikah pada Mahasiswa saat ini.

Selain itu, beberapa pendapat pihak yang berwenang memberikan penjelasan bahwa salah satu yang menyebabkan perilaku tersebut terjadi karena bukan hanya kurangnya kontrol dari masyarakat pada umumnya namun ketidak adanya aturan-aturan dari para pemilik kos yang memberikan kebebasan terhadap para anak-anak kos tersebut.

Berdasarkan dari hal tersebut, kebebasan yang diberikan Mahasiswa kos-kosan merupakan salah satu penyebab dari munculnya perilaku seks bebas diluar nikah di kelurahan Mahasiswa. Selain itu juga, dengan tidak adanya aturan yang di peruntukkan terhadap para Mahasiswa menyebabkan ketidak adanya batasan-batasan dalam berperilaku, seperti halnya dalam segi pakaian dan lain sebagainya yang menyebabkan munculnya perasaan seks bagi lawan jenis. Oleh karena itu, dari perilaku tersebut akan memunculkan tindakan-tindakan yang muncul secara sepontanitas tanpa memikirkan akibat dari apa yang dikerjakannya.

Dalam hal ini, teori Weber menjelaskan bahwa tindakan yang muncul atas dasar perasaan yang dimilikinya dan dapat muncul secara sepontanitas ketika mengalami suatu kejadian maka tindakan tersebut termasuk dalam tipe tindakan afeksi. Maka dalam hal ini cukup jelas bahwa berawal dari ketidak adaanya aturan dari pemilik kos dan disertai dengan ketidak adaannya kontrol dari masyarakat umun di Kelurahan Mangasa terharap perilaku Mahasiswa tersebut maka dapat memunculkan perilaku yang melanggar norma di masyarakat.

Berdasarkan paradigma dalam sosiologi dari George Ritzer yang terdiri dari tiga paradigma : Paradigma Fakta Sosial (social fact paradigm), Paradigma Definisi Sosial (social definition paradigm) dan Paradigma Perilaku Sosial (social behavior paradigm), dimana ketiga paradigma tersebut cukup relevan untuk mengkaji permasalahan tentang perilaku seks pranikah di kalangan Mahasiswa.

Weber memandang sosiologi sebagai ilmu yang berusaha untuk menafsirkkan dan memahami (interpretative understanding) tindakan sosial serta antar hubungan sosial untuk sampai pada penjelasan kausal mengenai arah dan konsekuensi tindakan sosial itu. Tindakan sosial menurut Weber sendiri adalah tindakan individu sepanjang tindakan itu mempunyai makna dan arti subyektif bagi dirinya dan diarahkan kepada tindakan yang nyata-nyata diarahkan kepada orang lain, juga dapat berupa tindakan yang bersifat membatin atau bersifat subyektif yang mungkin terjadi karena pengaruh positif dari situasi tertentu atau merupakan tindakan perjuangan dengan sengaja sebagai akibat dan pengaruh situasi yang serupa atau berupa persetujuan secara pasif dalam situasi tertentu (Ritzer, 2003 :38)

\section{SIMPULAN DAN SARAN}

Terjadinya perilaku seks yang dilakukan oleh mahasiswa kos-kosan didaerah alaudin, penyebab dan tanggapan pemerintah setempat, maka peneliti dapat menarik kesimpulan yaitu (i) perilaku seks diluar nikah pada mahasiswa kos-kosan daerah Alaudin karena disebabkan oleh kurangnya kontrol dari pemilik kos, orang tua dan kekuatan cinta sehingga perilaku seks tersebut marak terjadi di kalangan mahasiswa khususnya mahasiswa kos-kosan daerah Alauddin. (ii) faktor determinan yang menjadi penyebab munculnya perilaku seks diluar nikah adalah faktor internal yaitu karena benturan ekonomi dari mahasiswa itu sendiri, perasan cinta, kontrol pemilik kos. (iii) tanggapan tokoh masyarakat terkait dengan perilaku seks diluar nikah pada mahasiswa kos-kosan daerah Alauddin adalah kurangnya respon masyarakat 
Syahban Nur. Perilaku Menyimpang Studi Kasus Perilaku Seks diluar Nikah Mahasiswa Kos-Kosan Alauddin Kelurahan Mangasa Kecamatan Tamalate Kota Makassar

terhadap perilaku seks yang dilakukan oleh mahasiswa

\section{DAFTAR RUJUKAN}

Bandel, Kartin. 2006. Sastra Perempuan Seks. Yogyakarta: Jalasutra.

Basri, Hasan. 2000. Remaja Berkualitas Problematika Remaja Dan Solusinya. Yogyakarta: Pustaka Pelajar

Bungin, B. 2007. Penelitian Kualitatif: Komunikasi, Ekonomi, Kebijakan Publik, dan Ilmu Sosial Lainnya. Jakarta: PT Prenada Media Group.

Dianawati, Ajen. 2003. Pendidikan Seks Untuk Remaja. Jakarta: Kawan Pustaka.

[5]Kartono, K. 1988. Psikologi Remaja. Jakarta: CV Rajawali , 1997. Patologi Sosial. Jakarta: PT Raja Grafindo Persada ,2005. Patologi Sosial 2 Kenakalan Remaja. Jakarta: PT Raja Grafindo Persada

Köhlberg, L. 1995. Tahap-Tahap Perkembangan Moral (alih Bahasa: John de Santo dan Agus Cremmers). Yogyakarta: Kanisius

Kuper, Adam \& Jessica Kuper. 2005. Ensiklopedi Ilmu-Ilmu Sosial. Edisi ke-2. Jakarta: PT. Raja Grafindo Persada

Mussen, P.H. 1994. Perkembangan dan Kepribadian anak (Terjemahan Budijanto, F.X., dkk) Jakarta : Arehan

Mulyono, Y Bambang. 2005. Pendekatan Analisis Kenakalan Remaja dan
Penanggulangannya. Yogyakarta : Kanisius..

Pratidarmanastiti, L. 1991. Perkembangan Moral Remaja Delinkuen Dan Non Delinkuen. Tesis (tidak diterbitkan). Yogyakarta: Fakultas Psikologi Universitas Gajah Mada.

Ritzer, George. Douglas J. Goodman. 2008. Teori Sosiologi; Dari Teori Sosiologi Klasik Sampai Perkembangan Mutakhir Teori Sosial Postmodern. Yogyakarta: Kreasi wacana.

Ritzer, George. 2010. Sosiologi Ilmu Pengetahuan Berparadigma Ganda. Jakarta: Rajawali Pers.

Siahaan Jokie MS. 2009. Perilaku Menyimpang Pendekatan Sosiologi. Depok : PT Malta

Salisa, Anna, 2010, Perilaku Seks Pranikah Di Kalangan Remaja; (Studi Deskriptif Kualitatif Tentang Perilaku Seks Pranikah Di Kalangan Remaja Kota Surakarta), Skripsi; Universitas Sebelas Maret Surakarta.

Sadli, Saparinah. 1983. Persepsi Sosial Dalam Perilaku Menyimpang. Jakarta : Gramedia.

Supardan, Dadang. 2011. Pengantar Ilmu Sosial; Sebuah Kajian Pendekatan Struktural. Jakarta: PT. Bumi Aksara.

Sustiwi, Fadmi. 2 Mei 2005. Ketika Perilaku Seks Remaja Kian Beresiko. Semarang : Kedaulatan Rakyat, halaman 15

Suseno, Franz Magnis. 1987. Etika Dasar Masalah-Masalah Pokok Filsafat Moral. Yogyakarta: Kanisius 
Syahban Nur. Perilaku Menyimpang Studi Kasus Perilaku Seks diluar Nikah Mahasiswa Kos-Kosan Alauddin Kelurahan Mangasa Kecamatan Tamalate Kota Makassar 